\title{
1. The challenge of corporate governance
}

\subsection{THE GLOBAL FINANCIAL CRISIS AND FAILURES OF CORPORATE GOVERNANCE}

The world-wide crisis in financial markets and, in particular, the repercussions on equities markets around the world consequent on the 'credit crunch' of 2008-09 and beyond has once again focused attention on corporate governance. Indeed, the fallout from the Global Financial Crisis (GFC) continues to have dramatic regulatory, social, economic and political effects around the world. ${ }^{1}$

The crux of the GFC is widely acknowledged as a combination of failures in regulatory supervision, 'gate-keeping' by intermediaries, greed and fundamental failings of internal corporate governance. ${ }^{2}$ Yet, pre-GFC corporate collapses such as those of Enron and WorldCom in the US, ${ }^{3}$ HIH Insurance in Australia ${ }^{4}$ and collapses in other countries painted a

1 Julia Black, 'Paradoxes and Failures: "New Governance" Techniques and the Financial Crises' (2012) 75(6) MLR 1037. See especially 1037-41. For the largest government 'bailout' in history, see the US government's Troubled Assets Relief Programme ('TARP'). A component of TARP is enacted under the Emergency Economic Stabilization Act of 2008, H.R. 1424, accessed 3 February 2015 at http://frwebgate.access.gpo.gov/cgi-bin/getdoc.cgi?dbname=110_cong bills\&docid=f:h1424enr.txt.pdf ('EESA'). For further information on TARP and the EESA, see House Committee on Financial Services at http://financialservices. house.gov/ (accessed 6 March 2015). For a description of the EESA's passage through the House, Senate and President's signature, see http://www.govtrack.us/ congress/bill.xpd?bill=h110-1424 (accessed 6 March 2015).

2 Black, ibid.

3 The Enron collapse is examined in detail in Chapter 5.

4 For a discussion of the corporate collapses of HIH Insurance and One.Tel in Australia and the regulatory responses to corporate collapses in various jurisdictions, see Jennifer G Hill, 'Regulatory Responses to Global Corporate Scandals' (2005) 23 Wisconsin International Law Journal 367; Sydney Law School Research Paper No 06/35; Vanderbilt Law and Economics Research Paper No 06-04, accessed 3 February 2015 at SSRN: http://ssrn.com/ abstract $=886104$. 
similar picture. More recently, collapses such as that of the Hastie Group in Australia in $2012^{5}$ prompt this book to examine what lessons from these collapses have failed to be learnt? And what measures could have been taken - prospectively - to avoid the abyss?

Flowing from this, the following questions are posed by this book:

- What behaviours of corporate actors such as the individual directors, the CEO and management were present in these collapses and what are the consequences of these behaviours for firm survival or (in today's parlance) sustainability?

- What is the regulatory corporate governance environment which applies to these companies and how do individual corporate governance measures, mechanisms and processes (called 'governance variables') operate in the real world to enhance or reduce the effects of these behaviours?

- What are the 'core' or 'central' failures in governance variables that arise in corporate collapses?

- How do these governance variables interact with each other, that is, what are the relationships between governance variables?

- And which corporate governance variables are relatively more important - again, in the real world - in determining the survival or sustainability of the publicly-traded for-profit corporation?

These key questions at the heart of corporate governance discourse are the focus of this book. It proposes a diagnostic tool to prospectively analyse and assess the governance 'health' of individual companies and to both predict and enhance firm survival.

5 See PPB Advisory, Hastie Group Limited and Specific Subsidiaries, Report by Joint and Several Administrators Pursuant to Section 439A of the Corporations Act 2001, 21 January 2013, accessed 3 February 2015 at http://www. ppbadvisory.com/creditor-information/v/281/hastie-group/2nd-creditor-meeting ('Administrators' Report'). The collapse of the Hastie Group is examined in detail in Chapter 5. 


\subsection{SEPARATION OF OWNERSHIP FROM MANAGEMENT AND THE ROLE OF CORPORATE GOVERNANCE}

\subsubsection{The Balancing of Interests of 'Insiders' and 'Outsiders'}

The corporate governance sphere - indeed, on some views, the corporation itself $^{6}$ - involves a balancing exercise between corporate 'insiders' such as the directors, CEO and management with 'outsiders' such as shareholders or investors, employees, lenders, suppliers, regulators and, increasingly, social and environmental interests. The insider and outsider designations flow from the traditional separation of ownership (shareholders) from management or control (directors) in publicly-traded companies. One of the most influential definitions of corporate governance by Sir Adrian Cadbury in 1992 emphasises this separation:

[c]orporate governance is the system by which companies are directed and controlled. Boards of directors are responsible for the governance of their companies. The shareholders' role in governance is to appoint the directors and the auditors and to satisfy themselves that an appropriate governance structure is in place. The responsibilities of the board include setting the company's strategic aims, providing the leadership to put them into effect, supervising the management of the business and reporting to shareholders on their stewardship. The board's actions are subject to laws, regulations and the shareholders in general meeting. ${ }^{7}$

6 For a detailed discussion, see the papers relating to the 'nexus of contracts' theory and the 'anti-contractarian' views of the firm from the symposium on contractual freedom in corporate law held on 9 and 10 December 1988 at Columbia Law School, published at (1989) 89 Colum L Rev 1395.

7 The Committee on the Financial Aspects of Corporate Governance and Gee and Co Ltd, Report of the Committee on the Financial Aspects of Corporate Governance, 1 December 1992, London: Burgess Science Press ('Cadbury Report'), Para 2.5. For an earlier discussion of the definitions in this section, see Francesco de Zwart (90\% author) and George Gilligan, 'Comparative Corporate Governance Schemes and their Relevance for the Sporting Sector', Monash University Department of Business Law and Taxation, Working Paper No 16 (November 2008), accessed 3 February 2015 at http://ssrn.com.abstract $=1295682$, 6-7.

For the development of corporate governance, see Brian R Cheffins, 'The History of Corporate Governance', Oxford Handbook Of Corporate Governance, Mike Wright, Donald Siegel, Kevin Keasey and Igor Filatotchev, eds., Oxford University Press, 2013; University of Cambridge Faculty of Law Research Paper No. 54/2011; ECGI - Law Working Paper No. 184/2012, (December 1, 2011), accessed 24 April 2015 at SSRN: http://ssrn.com/abstract=1975404. 
In another influential definition, written more than ten years later, the OECD explained the meaning and purpose of corporate governance in a manner which classifies governance variables as measures or mechanisms which seek to punish or deter management misconduct or which seek to align the interests of insiders with outside shareholders:

[c]orporate governance involves a set of relationships between a company's management, its board, its shareholders and other stakeholders. Corporate governance also provides the structure through which the objectives of the company are set, and the means of attaining those objectives and monitoring performance are determined. Good corporate governance should provide proper incentives for the board and management to pursue objectives that are in the interests of the company and its shareholders and should facilitate effective monitoring. ${ }^{8}$

For a long time now, various theories and models of the Anglo-American corporate firm, international and national corporate governance codes and an ever-increasing body of theoretical literature and empirical studies have sought to explain the interaction between these corporate insiders and outsiders. Again, the book begins with these theories and models.

\subsubsection{Separation of Ownership, 'Nexus of Contracts', Agency Costs and the Shareholder Model}

The well-known theories and models relating to the separation of ownership and management of the corporation are the 'nexus of contracts', agency theory, the shareholder (primacy) model (and its related shareholder wealth-maximisation principle), the stakeholder model and the director primacy model.

\section{Statement of the nexus theory}

Bainbridge explains the nexus of contracts theory as follows:

For the development of US corporate governance, see Brian R Cheffins, 'The History of Modern U.S. Corporate Governance: Introduction', Edward Elgar's Corporate Governance in the New Global Economy Series, 2011; University of Cambridge Faculty of Law Research Paper No. 29/2012, accessed 24 April 2015 at SSRN: http://ssrn.com/abstract $=2192151$.

8 Organisation for Economic Co-Operation and Development, OECD Principles of Corporate Governance 2004, 2004, OECD Publications Service, Paris ('OECD Principles'), Preamble, p 11. See http://www.oecd.org/document/ 49/0,3343,en_2649_34813_31530865_1_1_1_37439,00.html (accessed 3 February 2015). 
[n] exus of contracts theory visualizes the firm not as an entity, but as an aggregate of various inputs acting together to produce goods or services. Employees provide labor. Creditors provide debt capital. Shareholders initially provide equity capital and subsequently bear the risk of losses and monitor the performance of management. Management monitors the performance of employees and coordinates the activities of all the firm's inputs. The firm is seen as simply a legal fiction representing the complex set of contractual relationships between these inputs. ${ }^{9}$

According to Easterbrook and Fischel and, separately, Bratton, the effect of the nexus of contracts theory is to discourage management misconduct in the publicly-owned and traded corporation. ${ }^{10}$ In short, welfare-reducing terms of the contract (or, more accurately, the various contracts or relationships) between the various actors cause a reduction in market price and, therefore, return on investment causing investors to seek more profitable investments. For publicly-traded firms, the 'market for corporate control' acts in conjunction with the nexus of contracts theory to further discourage management misconduct.

The market for corporate control operates as part of the efficient market hypothesis to punish management which engages in value- or performance-reducing behaviour. Cunningham explains that the efficient market hypothesis operates on the assumption that share prices can accurately reflect the corporation's value ${ }^{11}$ so that a (lower) share price will reflect poor performance and, by proxy, poor management leaving the firm open to, among other things, hostile takeover and removal of management. ${ }^{12}$ Cunningham also notes that the market for corporate control

9 Stephen M Bainbridge, 'In Defense of the Shareholder Wealth Maximization Norm' A Reply to Professor Green” (1993) 50 Washington \& Lee Law Review 1423, accessed 3 February 2015 at SSRN: http://ssrn.com/abstract $=303780$, 1426-7 (footnote omitted).

10 Frank H Easterbrook and Daniel R Fischel, 'The Corporate Contract' (1989) 89 Colum L Rev 1416, 1430 and 1430-1 and William W Bratton, 'The "Nexus Of Contracts" Corporation: A Critical Appraisal' (1989) 74 Cornell L Rev 407, 417 and 418.

11 Easterbrook and Fischel, ibid, 1430-1 and Lawrence A Cunningham, 'Behavioral Finance and Investor Governance' (2002) 59 Washington \& Lee Law Review 767, accessed 3 February 2015 at SSRN: http://ssrn.com/abstract $=255778$, 3. The author cites Donald C Langevoort, 'Theories, Assumptions and Securities Regulation: Market Efficiency Revisited' (1992) 140 U Pa L Rev 85. See also, Eugene F Fama, Michael C Jensen, Lawrence Fisher and Richard Roll, 'The Adjustment of Stock Prices to New Information' (1969) 10 International Economic Review 1-22, accessed 3 February 2015 at SSRN: http://ssrn.com/ abstract $=321524$.

12 Easterbrook and Fischel, above n 10, 1430-1 and Cunningham, ibid. 
is assisted by other governance measures - in particular, 'reputational constraints' (and consequences) relating to individual managers. ${ }^{13}$

\section{Agency theory}

Commentators such as Jensen and Meckling have sought to explain the separation effect in terms of agency (costs) theory. ${ }^{14}$ Examined in detail in Chapter 4, this theory posits that, when making decisions, insiders or 'agents' should act on behalf of the outsiders or 'principals'. However, the agent's own self-interest in 'shirking', empire building, compensation, perks and other advantages may cause directors, CEOs and managers to deviate from what is in the shareholders' best interests. As a result, the shareholders incur costs to 'monitor' and 'bond' with the directors/ managers as well as other 'residual' costs. ${ }^{15}$

For Jensen and Meckling, thus, the for-profit corporation (and even a non-profit organisation) is effectively a nexus of contracts: ${ }^{16}$

which is also characterized by the existence of divisible residual claims on the assets and cash flows of the organization which can generally be sold without permission of the other contracting individuals. ${ }^{17}$

Thus, the agency (cost) relationship between 'insider-managers' and 'outsider-shareholders' underpins the nexus model. In the shareholder (or shareholder primacy) model of corporate governance, the shareholders are the only residual claimants. ${ }^{18}$ Thus, it is the residual nature of

13 Cunningham, above $\mathrm{n} 11,3$.

14 See discussion in section 4.2.3.1 of Chapter 4.

15 The classic formulation is found in Michael C Jensen and William H Meckling, 'Theory of the Firm: Managerial Behavior, Agency Costs and Ownership Structure' in Michael C. Jensen, A Theory of the Firm: Governance, Residual Claims and Organizational Forms, Cambridge, MA: Harvard University Press, December 2000; (1976) 3(4) Journal of Financial Economics, accessed 3 February 2015 at SSRN: http://ssrn.com/abstract $=94043,5-6$.

16 Jensen and Meckling, ibid, 8-9. For further discussion of the nexus of contracts theory of the firm and corporate law, see Stephen M Bainbridge, 'The Board of Directors as Nexus of Contracts: A Critique of Gulati, Klein \& Zolt's "Connected Contracts" Model', UCLA, School of Law Research Paper No 02-05, January 2002, accessed 3 February 2015 at SSRN: http://ssrn.com/ abstract $=299743$, 9-11 and Bainbridge, above n 9, 1426-7.

17 Jensen and Meckling, above n 15, 8-9.

18 Gerard J Charreaux, 'Corporate Governance Theories: From Micro Theories to National Systems Theories' (January 2004), Universite de Bourgogne Fargo Working Paper No 1040101, accessed 3 February 2015 at SSRN: http://ssrn.com/ abstract $=486522$, 8; Amir N Licht, 'The Maximands of Corporate Governance: A Theory of Values and Cognitive Style' (November 2003), ECGI - Law 
the shareholders' position which defines the shareholder as the central element of the shareholder primacy model and its related shareholder wealth-maximisation principle which follows.

\subsubsection{The Shareholder Wealth-maximisation Principle}

For Roe, the interests of shareholders and managers are aligned in part by managerial 'belief' in the shareholder wealth-maximisation principle (which he calls a 'soft control'). ${ }^{19}$ In United States corporate (case) law, the origin of the shareholder wealth-maximisation principle is often said to arise from the decision in Dodge v Ford Motor Co. ${ }^{20}$ The correctness of this principle, at least as having been derived from Dodge v Ford Motor Co, has been challenged. ${ }^{21}$ Despite this, the principle permeates much of US corporate law, including, as one example, the fiduciary duties of directors. ${ }^{22}$

In the case of Australian law, a similar situation exists. Subsection 181(1) (a) of the Corporations Act provides that a director's powers and duties must be exercised 'in good faith in the best interests of the corporation. ${ }^{23}$ While expressed to be owed to the corporation, it is well-known from the Australian High Court's decision in Walker $v$ Wimborne ${ }^{24}$ that this means, in the general case and apart from situations of insolvency or near insolvency of the corporation, that the duties must be exercised for the benefit of its shareholders as a whole..$^{25}$

Working Paper No 16/2003, accessed 3 February 2015 at SSRN: http://ssrn. com/abstract $=469801$ and (2004) 29(3) Delaware Journal of Corporate Law 649-746, accessed 3 February 2015 at SSRN: http://ssrn.com/abstract $=764025$, 4. For a discussion of the nature of agency costs and residual claims in different forms of organisation, see Eugene F Fama and Michael C Jensen, 'Separation of Ownership and Control' in Michael C Jensen, Foundations Of Organizational Strategy, Cambridge, MA: Harvard University Press, 1998 and (1983) 26 Journal of Law and Economics 301, accessed 3 February 2015 at SSRN: http://ssrn.com/ abstract $=94034$.

19 Mark J Roe, 'Political Preconditions To Separating Ownership from Corporate Control' (2000) 53 Stanford Law Review 539, accessed 3 February 2015 at SSRN: http://ssrn.com/abstract $=165143,554-5$.

20 Dodge v Ford Motor Co (1919) 204 Mich 459, 507; 170 NW 668; 684 (per Ostrander J, Steere, Fellows, Stone and Brooke JJ concurring).

21 Lynn A Stout, 'Why We Should Stop Teaching Dodge v. Ford' (September 2007), UCLA School of Law, Law-Econ Research Paper No 07-11, accessed 3 February 2015 at SSRN: http://ssrn.com/abstract=1013744.

22 Douglas G Baird and M Todd Henderson, 'Other People's Money' (2008) 60 Stanford Law Review 1309, Symposium Issue, 2008, accessed 3 February 2015 at SSRN: http://ssrn.com/abstract=1017615.

23 Corporations Act 2001 (Cth), section 181(1)(a) (emphasis added).

24 Walker $v$ Wimborne [1976] HCA 7; (1976) 137 CLR 1 (3 March 1976).

25 Ibid (1976) 137 CLR 1, 7 (per Mason J). 


\section{3 'CORE' AREAS OF CORPORATE GOVERNANCE AND CORPORATE FAILURES}

In Chapter 6, the 'relational approach' proposed by this book identifies a 'model' or comparative scheme in table-form which can be used as a benchmark in the comparison of all cross-border and national governance codes. The chapter assesses the position and relative importance of governance variables from this comparative scheme to identify - as a measure of continuity and relative importance - a smaller 'core' set of governance variables for the international/cross-border sector and each of the national sectors of the US, UK and Australia. Looking ahead to Chapter 6, these core governance variables are:

- timely/regular disclosure of information;

- questions and voting in meetings;

- interested or conflicted director disclosure;

- employee/management/director incentive and participation schemes;

- timely disclosure of material information including remuneration policies;

- independent/external audit;

- quality and integrity of information;

- board functions and independence - compliance with statutory and legal duties on organisation/directors;

- principal board responsibilities - corporate governance compliance;

- principal board responsibilities - selection and monitoring of key management;

- principal board responsibilities - fair and open election of directors;

- principal board responsibilities - interested director or management conflicts or transactions;

- principal board responsibilities - reporting, audit, financial/ operational control, risk management and internal audit;

- independence from management - non-executive/independent directors; and

- independence from management - responsibilities of board sub-committees delineated and disclosed. ${ }^{26}$

These core governance variables are in turn used to construct the central elements of the relational approach in this book. For present purposes, however, it is illustrative for the separation of ownership from

\footnotetext{
26 See discussion in section 6.8 .1 below.
} 
management to identify which of these governance variables are central to the pre- and post-GFC corporate collapses of Enron and the unfolding story of the Hastie Group.

\subsubsection{Multiple Failures in Core Governance Variables}

In Chapter 5, a detailed examination of the Enron corporate collapse is juxtaposed with that of the Hastie Group. But an overview of the Enron and Hastie facts is illustrative for introductory purposes of the challenges posed for any system of corporate governance.

Enron was the seventh largest US company at the time of its collapse. Indeed, Gordon observes that:

The Enron case has seemed particularly disturbing because the case represents a failed stress test for many institutions of US shareholder capitalism, circa 1990s. As with most catastrophes, many separate systems simultaneously failed: auditing and accounting, executive compensation, internal monitoring by the board, and external monitoring by securities analysts. ${ }^{27}$

The Enron share price remained high despite the close attention of institutions and analysts. ${ }^{28}$ For Gordon, the complexity of the company's structure and off-balance sheet transactions caused information asymmetry problems obscuring its true (and much lower) value. ${ }^{29}$ Each of Enron's traders was a separate profit centre causing 'phantom' profits to be recorded ${ }^{30}$ Off-balance sheet entities - in particular 'Special Purpose Entities' (SPEs) - caused the valuation and solvency of those entities to be problematic. $^{31}$

By contrast, danger signs for the Hastie Group were prominent. After listing on the ASX, Hastie Group Limited ('HST') acquired a number

27 Jeffrey N Gordon, 'Governance Failures of the Enron Board and the New Information Order of Sarbanes-Oxley', Columbia Law and Economics Working Paper No 216; Harvard Law and Economics Discussion Paper No 416 (March 2003), accessed 3 February 2015 at SSRN: http://ssrn.com/abstract=391363, 3 (emphasis added).

28 See discussion in section 5.2.1.1 of Chapter 5.

29 Jeffrey N Gordon, 'What Enron Means for the Management and Control of the Modern Business Corporation: Some Initial Reflections' (2002) 69 University of Chicago Law Review 1233, accessed 3 February 2015 at SSRN: http://ssrn.com/ abstract $=305343,6$.

30 Douglas G. Baird and Robert K. Rasmussen, 'Four (or Five) Easy Lessons From Enron' (2002) 55 Vanderbilt Law Review 1787, accessed 3 February 2015 at SSRN: http://ssrn.com/abstract $=358442,118$.

31 Ibid, $120-122$. 
of businesses - many overseas - emerging with '7,000 employees, turnover in excess of $\$ 1.8 \mathrm{~b}$, construction work-in-progress (WIP) of \$2.9 [billion] and assets employed of nearly \$1 [billion]'.32 The Group then experienced a dramatic decline in profitability which required five profit downgrades from November 2010 to May 2012. ${ }^{33}$ The company was required to enter a moratorium agreement with its bankers ${ }^{34}$ and then raised $\$ 158$ million to repay debt..$^{35}$ Large write-downs were made against its major assets including goodwill, receivables and work-inprogress totaling \$254 million ${ }^{36}$ and trading in Hastie Group shares were suspended twice, the latter accompanied by accounting irregularities of $\$ 20$ million. ${ }^{37}$ The Group was placed into administration on 28 May $2012 . .^{38}$

Enron director independence was undermined by various factors. Branson is critical of high fees and consulting contracts for directors. ${ }^{39} \mathrm{But}$ share and option holdings were argued to reduce the quality of monitoring ${ }^{40}$ as was Enron's director compensation policy. ${ }^{41}$ Internal decisionmaking at Enron was typified by familiarity between board members and deference to management ${ }^{42}$ while the ultra-competitive culture at Enron undermined risk-management controls by stifling dissent and driving misconduct in the pursuit of profit. ${ }^{43}$ In the Hastie collapse, too, there were significant inadequacies in the Hastie audit committee, monitoring and control including that 'the Audit and Risk Committee ... was largely inactive $^{34}$ as well as inadequate operational management processes,

32 Administrators' Report, above n 5, section 2.5.1, p 12 of 99

33 Ibid, Timeline of Key Events Leading Up To the Administration of the Hastie Group, p 17 of 99.

34 Ibid.

35 Ibid, section 2.5.2, p 13 of 99 .

36 Ibid.

37 Ibid.

38 Ibid, section 2.1, p 10 of 99.

39 Douglas M Branson, 'Enron - When All Systems Fail: Creative Destruction or Roadmap to Corporate Governance Reform?' (2003) 48 Villanova Law Review 989; Villanova Law/Public Policy Research Paper No 2003-13, accessed 3 February 2015 at SSRN: http://ssrn.com/abstract=473205, 1003.

40 Stuart L Gillan and John D Martin, 'Financial Engineering, Corporate Governance, and the Collapse of Enron', U of Delaware Coll. of Bus. and Econ. Ctr. for Corp. Governance Working Paper No 2002-001 (November 2002), accessed 3 February 2015 at SSRN: http://ssrn.com/abstract=354040, 23-4.

41 Ibid, 24.

42 See discussion in section 5.2.2.2 below.

43 See discussion in section 5.2.2.3.2 below.

44 Administrators' Report, above n 5, section 2.5.3, p 14 of 99. 
reporting systems and interrogation and control by the board in relation to management. ${ }^{45}$

The Enron collapse was typified by significant earnings manipulation ${ }^{46}$ again stemming from the use of off-balance sheet SPEs to hide debt and minimize tax. ${ }^{47} \mathrm{CEO}$, executive and director compensation - particularly in the form of equity and share options - exacerbated earnings manipulation. ${ }^{48}$ At Hastie too, the Administrators found significant culture problems in Hastie financial results and forecasts including that 'there appears to have been a general culture of ignoring bad news ...' and 'the Board, prior to the appointment of the interim CEO . . . appeared not to have "an enquiring mind" as to [the] reliability of financial statements and overall reporting', 49

Significant, too, in the Enron collapse was the undermining of external auditor independence leading to a massive audit failure by Enron's auditors, Arthur Andersen. This was said to be principally on account of the significant amount of non-audit tax services, ${ }^{50}$ Andersen's role as both internal and external auditor ${ }^{51}$ and the practice of Enron hiring former Andersen employees. ${ }^{52}$ The Administrators have also raised issues in relation to the Hastie Group audit querying the auditor's compliance with a number of Australian Auditing Standards. ${ }^{53}$

Even from this brief overview, there are important similarities and differences in the two collapses for drawing out themes and tensions for regulators, policy-makers, law reformers and corporate actors. These are examined in detail in Chapter 5.

\subsubsection{Key Fields and Research Questions in Firm Sustainability}

In the relational approach, there are four 'Key Fields' which represent a simulation of the 'real world' sphere of corporate governance discourse. In other words, these are the four areas which will be examined in order to

\footnotetext{
45 Ibid. See also, section 7.9, p 61 of 99 and section 7.9.5, p 65 of 99.

46 See discussion in section 5.2 .3 below.

47 See discussion in section 5.2.3.1 below.

48 See discussion in section 5.2.3.2.1 below.

49 Administrators' Report, above n 5, section 2.5.3, p 14 of 99.

50 See discussion in section 5.2.4.2 below.

51 Matthew J Barrett, 'Enron and Andersen - What Went Wrong and Why Similar Audit Failures Could Happen Again', accessed 3 February 2015 at SSRN: http://ssrn.com/abstract=794831, 159.

52 Ibid, 160.

53 Administrators' Report, above n 5, section 7.11, p 67 of 99.
} 
construct the relational approach to examining the governance health and sustainability of the corporation:

1. Application of the Principal Theories of the Firm to the Relational Approach;

2. 'Autopsies' of the Enron and Hastie Corporate Collapses;

3. Comparative Corporate Governance Codes; and

4. Empirical Studies of the Effectiveness of Governance Variables.

\section{How are the Key Fields selected?}

The four Key Fields are the most significant and influential areas of corporate governance discourse measured by the number of articles and/ or working papers. Thus it is important to explain how the four Key Fields were selected in order to substantiate the legitimacy of decisions taken regarding the identity of the governance variables examined in the book and the structure and components of the relational approach.

The Key Fields are selected from the single most current and voluminous collection of works in the very wide expanse of corporate governance - the e-library of the Social Science Research Network (SSRN) ${ }^{54}$ A search was undertaken in 2007 using the general 'corporate governance' search term. Of course, it is not possible even in a work this size to discuss all these works. The works chosen were selected for relevance and impact. Thus a qualitative element was added to the selection process by discussing works that are important or representative in hypothesising the actual real world behaviour of governance variables.

Because of considerations of scope and size, it was necessary to exclude from this initial collection on SSRN - and thereafter - works relating to the perceived effects of various areas of governance inquiry including, principally:

- accounting and auditing principles, standards and governing or regulatory bodies;

- governance of private firms and semi-government, non-profit or voluntary firms/organisations;

- the fiduciary duties of directors under the laws of equity or statute; and

54 See http://www.ssrn.com (accessed 3 February 2015). References in this book to working papers from the SSRN website will bear the date of posting and/or revision of the papers as signified in the suggested citation by SSRN. 
- detailed theories, examinations and applications of principles of corporate social responsibility or CSR except interests that affect or influence the stakeholder model as described in Chapter 4.

In 2012, the next stage of review of SSRN literature was undertaken to update the works within the four Key Fields. Again, the general 'corporate governance' search term was used. The works chosen were selected for relevance and impact from a sample of 250 works with the highest download figures over the preceding three years, the lowest with approximately 395 downloads. The next review of SSRN literature took place from 20 December 2013 to 6 January 2014 again using the 'corporate governance' search term. Again, the works chosen were selected for relevance and impact from a sample of 200 works with the highest download figures spanning the previous two years with the lowest download figure of 277 downloads. The final review took place from 9-14 October 2014 encompassing 100 works spanning the previous year with the lowest download figure of 155 downloads.

The book now introduces each Key Field as the structural foundation of the relational approach. Each component of the relational approach and the governance variables themselves - are identified after examination of one or more Key Fields.

\subsubsection{Key Field No 1 - Application of the principal theories of the firm to the relational approach}

Key Field No 1 examines the application of the pre-eminent theories and models of the firm to the relational approach. Key Field No 1 demonstrates how the relational approach adds explanatory power to these theories.

The key questions in section 1.1 asked what behaviours of the individual directors, CEO and management were present in corporate collapses and what are the consequences of these behaviours for firm sustainability? So this Key Field asks:

- How do the pre-eminent theories and models seek to balance the competing interests between corporate insiders and outsiders?

- And how does the relational approach help to explain the operation of these theories and models?

\subsubsection{Key Field No 2 - 'Autopsies' of the Enron and Hastie corporate collapses}

The following Key Field No 2 describes how these theories are undermined in the case of corporate collapses like Enron and Hastie. This Key Field 
provides a detailed examination of the commentator views on the Enron corporate collapse as a pre-GFC example of corporate failure. Then juxtaposed is the relational approach's own comparison of the Hastie collapse from the post-GFC period. The key questions in section 1.1 seek the 'core' features of these collapses. Thus, the relational approach asks:

- What are the structural features of the Enron and Hastie corporate collapses in pre- and post-GFC times and how did they operate at the relevant time?

- And what lessons do they provide for a diagnostic approach or tool for regulators, policy-makers, law reformers and corporate actors and their advisors relating to the sustainability of the corporation?

\subsubsection{Key Field No 3 - Comparative corporate governance codes}

Two key questions in section 1.1 ask what is the regulatory corporate governance environment for corporations and which governance variables are relatively more important in determining the sustainability of the firm? Originally springing from a number of collapses last century including Enron, this Key Field examines the multitude of governance variables in the real world in which they operate. The Key Field examines codes for the international/cross-border sector and the US, UK and Australia.

Thus, Key Field No 3 asks:

- Which governance variables have developed over time and across sectors (international/cross-border and national) to form the central planks of governance codes and schemes?

\subsubsection{Key Field No 4 - Empirical studies on the effectiveness of governance variables}

The relational approach's key questions ask how individual governance variables operate in the real world to enhance or reduce the effects of corporate actors such as the board, individual directors, the CEO and management. Key Field No 4 thus examines a wide range of empirical and other studies which examine the effects of governance variables on shareholder wealth measures such as firm value/share price, firm operating performance/profit and the probability of earnings manipulation. The largest Key Field, it asks:

- What is the effectiveness of individual corporate governance variables in affecting the long-term efficiency and sustainability of the corporation? 
- What factors intervene to reduce the operation and effectiveness of these corporate governance variables?

- And what is the relative importance of individual corporate governance variables inter se in reducing (or increasing) agency costs and enhancing (or reducing) the long-term efficiency and sustainability of the for-profit firm?

\subsection{RELATIONAL CORPORATE GOVERNANCE}

Based on the underlying interrelationships, themes and tensions in these four Key Fields, the approach proposed for regulators, policy-makers, law reformers, corporate actors and their advisors in this book is called 'relational corporate governance'. It is based on identifying, describing and predicting the nature, behaviour and interrelationships between corporate governance variables. It is critical to the understanding of governance variables that they do not operate in isolation but have a significant 'zone of effect'. They affect the operation of other governance variables as well as other managerial and governance structures within the corporation.

The key goals or aims of relational corporate governance drawn from the four Key Fields above are to:

(1) introduce a new definition of 'corporate governance' that weighs or balances the aims, behaviours and positional conflict of insiders and outsiders. This is known as the 'three relational axes of good governance' and is introduced in Chapter 2,55

(2) create a 'simulated corporate governance environment' which represents the 'real world' sphere of corporate governance. These are the four Key Fields introduced above;

(3) Identify, describe and map diagrammatically the interrelationships, themes and tensions underpinning these four Key Fields. These are the eight 'governance factors' introduced below and the 'interrelationship schemes' between these factors presented in Chapter 2. ${ }^{56}$ The governance factors and interrelationship schemes are combined to create a 'relational effect path' for each governance variable;

(4) Create a comparative table or scheme system upon which to compare across sectors and over time the governance variables utilised in the major US, UK, Australian and international/cross-border for-profit

\footnotetext{
55 See the discussion in sections 2.3.1-2.3.3 below.

56 See Figures 2.6 and 2.7.
} 
corporate governance codes or schemes. These are the Governance Code Tables and Commonality Tables of Chapter 6; and

(5) As an over-arching aim, to propose an approach or tool for regulators, policy-makers, law reformers and corporate actors to predict, measure and enhance the relative importance of governance variables inter se in reducing (or increasing) agency costs and enhancing (or reducing) the long-term efficiency and sustainability of the for-profit firm.

\subsection{AGENCY COSTS AND SUSTAINABILITY IN THE RELATIONAL APPROACH}

A very good argument can be put that reducing agency costs causes the long-term efficiency and sustainability of the for-profit firm to be enhanced. If, as suggested by Jensen and Meckling, agency costs are reflected in the market price of shares, ${ }^{57}$ then reducing these costs on a long-term basis by the employment of governance variables could lead to long-term and sustained market value improvement.

Indeed, the express purpose of many of the empirical studies of the effectiveness of governance variables in the book is just this. For example, many of these studies seek to show that a collection of governance variables, or particular individual variables, enhance the monitoring of management and thus reduce agency costs. This, these studies argue, in turn enhances sustainability measures or proxies such as the firm's cost of capital, firm value and firm operating performance. In other studies, the agency cost:sustainability relationship may not be the express purpose but is the underlying tenor of the study. Indeed, this is also one of the underlying assumptions of the relational approach proposed in this book.

Thus the relational approach, being theoretical, will first assume in Chapters 2-6 that hypotheses can be made about governance variables in reducing (or increasing) such agency costs and that, in turn, the longterm efficiency and survival or sustainability of the for-profit firm may be enhanced (or diminished). Then, in Chapters 7-10, the book will examine empirical studies which reveal the real-world effects of governance variables on shareholder wealth measures such as firm value/share price, firm operating performance/profit and the probability of earnings manipulation. In future stages, the agency cost:sustainability relationship in this approach can be empirically tested.

\footnotetext{
57 See discussion in section 4.2 .3 below.
} 


\subsection{OVER VIEW OF THE BOOK}

\subsubsection{Overview of the Relational Corporate Governance Approach}

The approach for regulators, policy-makers, law reformers and corporate actors presented in the relational approach aims to evaluate and map on a 'first principles' basis the insider and outsider forces on the corporation and the nature, behaviour, effect and, consequently, relative importance of 39 corporate governance variables which arise in international and national corporate governance best practice and discourse.

\subsubsection{Introduction to Relational Approach Chapters}

Chapter 2 constructs the principal components of the relational approach and introduces the 39 governance variables. It begins with an overview of the argued micro- and macro-economic benefits of 'good' corporate governance. Then follows detailed analysis and justification for the four components. The 'three relational axes of good governance' - the theoretical weighing mechanism - are presented in descriptive and diagram form. These act as a set of scales to weigh the objectives, behaviours and positional conflict of insiders versus outsiders. The eight governance factors are the 'backbone' of the relational approach. They represent the most significant and recurring themes or aims underpinning the four Key Fields and, therefore, the 39 governance variables drawn from those Fields. The third component - the two interrelationship schemes represents the hypothesized interrelationships between the eight governance factors. These schemes are used later in the book to construct the fourth component - a relational effect path for each governance variable. This path depicts the number and identity of governance factors affected by each governance variable and the direction of the effect. The chapter culminates with a diagram of the overall relational corporate governance approach in Figure 2.8.

The hypothesised interrelationships between the governance variables and governance factors depicted in the relational effect paths are summarised in Chapter 3 in two operational tables. Table 3.1 displays the number and identity of each governance factor affected by a governance variable and the direction of the effect. Table 3.2 arranges the 39 governance variables in order or groups of descending relative importance (known as 'relational proximity rating') in affecting agency costs and the long-term efficiency and sustainability of the firm.

Chapters 4-10 cover a vast territory. They examine the four significant 
areas that simulate 'real-world' corporate governance discourse - the four Key Fields.

Chapter 4 contains an analysis and application of the principal theories and models of the firm explained in terms of the relational approach. The chapter shows that the relational approach adds explanatory power, components and examples to the currently pre-eminent theories of the firm - the 'nexus of contracts', agency theory, the shareholder (primacy) model, the stakeholder model and the director primacy model.

In Chapter 5, the theory in the preceding chapter is translated into a real-world case study of the behaviour of governance variables in one of the largest corporate collapses ever - the pre-GFC corporate collapse of Enron. Juxtaposed with this is the relational approach's own analysis of the post-GFC collapse of the Hastie Group. This chapter seeks to show three things. First, to extract the themes and tensions of the Enron collapse to support the identification, structure and articulation of the eight governance factors. Second, to identify the intervening factors or problems which reduced the effectiveness of the governance variables examined in the book. Finally, to show how these governance variables behaved in the multitude of governance failures of the Enron and Hastie corporate collapses.

The Enron corporate collapse (and others) spawned a large number of corporate governance codes of 'best-practice'. Chapter 6 is thus a comparative analysis of these and subsequent international and national corporate governance codes. The aim of Chapter 6 is two-fold. First, to produce a 'model' or comparative scheme in table-form which can be used as a benchmark or comparison for all governance codes. Second, to identify a smaller 'core' set of variables from international and national codes for justifying the selection of the themes and tensions in the three relational axes of good governance and the governance factors.

There follows the first of four parts on the Empirical Studies Key Field No 4.

In Chapter 7, the governance variables are examined to determine their effectiveness in reducing agency costs and increasing the long-term efficiency and sustainability of the firm. This is the first chapter which presents a relational effect path for each governance variable - this path sets out the number and identity of governance factors affected by the relevant governance variable and the direction of the effect. The relational effect paths are critical for two reasons:

- first, they are an interpretation/translation of the empirical studies into the components of the relational approach; and 
- second, to determine the relative importance of a governance variable $v i s$ - $\grave{a}$-vis other governance variables in reducing (increasing) agency costs and enhancing (reducing) the long term efficiency and sustainability of the firm. This is examined by proxies relating to firm operating performance/profit and firm value/share price. The greater the number of governance factors affected by a governance variable, the greater is that variable's relative importance relative to other variables.

Thus, Chapter 7 examines 'overall' governance (as a function of multiple governance variables), the strength of the national shareholder protection regime and 'Board Factors I' - director independence and the proportion of non-executive/independent directors.

Then, for Chapter 8, the governance variables examined are:

- 'Board Factors II' - board size and outside board positions of independent directors; and

- other firm-specific variables - anti-takeover mechanisms such as staggered board elections, audit subcommittee presence, independence and expertise, 'block' and institutional shareholdings and division in the $\mathrm{CEO} / \mathrm{Chairperson}$ roles.

Again, a relational effect path is presented for each governance variable and firm efficiency and sustainability is measured by firm operating performance and firm value.

In Chapter 9, the proxy for long-term efficiency and sustainability is earnings manipulation or management. Increases in earnings management represent increases in the agency costs of outside shareholders and therefore a fall in firm sustainability. The governance variables examined include many identified previously - but now assessed against the probability of earnings management/manipulation.

The purpose of Chapter 10 is to present the fourth and final part of the Empirical Studies Key Field No 4. The corporate governance effects of director, CEO and management compensation are examined with respect to the governance variables. The chapter constructs the relational effect paths for the compensation-related governance variables including director/CEO pay levels, equity/option holdings of directors and management and short-term options for directors and outside directors on the audit committee.

The relational approach concludes in Chapter 11 with observations and analysis relating to the interrelationships and relational proximity of the 39 governance variables. Links are drawn in relation to the themes and 
tensions underpinning the four Key Fields. Comparisons of the relational approach's findings on the relational proximity rating of governance variables are made against the current state of research in those Fields. Chapter 11 concludes with observations on the structure, explanatory power and scope of the relational approach as well as areas for future research. 